Hayashi,A.M.'; Shiguihara, C.A.'; Torro, C.A.'
Desta forma, iniciou-se administração de azatioprina na dose de $2 \mathrm{mg} / \mathrm{kg} / \mathrm{SID}$ durante 7 dias, observando-se manutenção da contagem plaquetária $\left(235.000 / \mathrm{mm}^{3}\right)$. A dose de azatioprina foi reduzida semanalmente até $0,7 \mathrm{mg} / \mathrm{kg} / \mathrm{cada} 48$ horas, com plaquetometria dentro da normalidade. $\mathrm{O}$ animal está há 70 dias recebendo esta dose de manutenção de azatioprina exclusivamente e não apresentou sintomas relacionados a efeitos colaterais. Até o momento, a droga mostrou-se uma boa alternativa na manutenção de pacientes que necessitem de terapia imunossupressora crônica.

\section{5 - Acupuntura e fitoterapia chinesa como medicina complementar em alterações locomotoras em cães. Relato de 3 casos}

\section{1- CEVEMEC - Centro Veterinário de Medicina Complementar, São Paulo-SP}

A acupuntura representa uma das técnicas de tratamento pela Medicina Tradicional Chinesa(MTC), acompanhada da fitoterapia chinesa e moxabustão. Sào usadas como armas terapêuticas complementares, ou seja em associação ao tratamento clínico ou cirúrgico, por exemplo $\mathrm{em}$ discopatias. Em alguns casos onde a resposta ao tratamento convencional nào é satisfatória ou há recidivas, além de impossibilidade de cirurgia(por variados motivos), a MTC pode ser outra forma de abordagem terapêutica. Decidiu-se a realização deste trabalho para demonstrar que a acupuntura associada com a fitoterapia chinesa potencializa o efeito da MTC, obtendo-se melhora clínica mais rápida.. Foram realizados os diagnósticos e tratamentos segundo a MTC em três casos de patologias locomotoras, utilizando-se as duas técnicas citadas, além da moxabustão. Foram feitas 4 sessōes com intervalos de 7 dias e depois 2 sessões com intervalos de 14 dias, com exceçào do caso 2 onde se acrescentou 1 sessào, além de iniciar em todos os casos a administração de fitoterapia chinesa logo na $1^{\mathrm{a}}$ semana da acupuntura. As avaliações de evolução clínica foram feitas sempre 1 semana após a sessão ter sido realizada. $\mathrm{O}$ caso 1 relata uma cadela de 5 anos que apresentava há 2 meses impotência funcional de membros posteriores com diagnóstico radiográfico de discopatia, com crises anteriores, há mais de 1 ano.Apresentava resposta ao estímulo doloroso, atrofia muscular discreta, teve infecção do virus da cinomose quando filhote, doença que pela MTC leva a um grande desgaste energético.Neste animal foram utilizados os seguintes pontos, dependendo da sessão: ID3, B62, R3/B60, BP6,VB39,VB34, E36, F8 com agulhas e estimulação manual, e os pontos B23 e VG4 com agulhas e moxabustão, e os pontos B20, B17 com moxabustão. Usadas fórmulas magistrais chinesas : Guei Fu Di Huang Wan e Gui Pi Tang. Logo na $1^{2}$ semana conseguiu apoiar e dar alguns passos, evoluindo bem a cada sessão, até locomoção normal. $\mathrm{O}$ caso 2 relata uma cadela de 5 anos com lombalgia crônica e impotência funcional de membros posteriores por discopatia, última crise há 2 meses, apresentando incontinência urinária, resposta ao estímulo da dor, porém diminuída no MPD.Os pontos usados são os mesmos do caso anterior, exceto B17, F8 e E36 e acrescentados VB30 e B28.Logo na $1^{2}$ semana observou-se andar atáxico intermitente, propriocepçaõ diminuida no MPD e mantendo-se em estação com facilidade, com melhora clínica a cada sessão incluindo a incontinência urinária, estabilização da locomoção atáxica discreta dos membros posteriores.As fórmulas usadas, segundo avaliaçào semanal foram: Bu Yang Huan Wu Tang, Xiao Huo Luo Dan, além das duas fórmulas do caso 1. O caso 3 relata um cão Rottweiler de 8 anos com síndrome cérvico-torácica há 1 semana sem resposta medicamentosa, com incapacidade de se manter em estação, hiperreflexia de membros posteriores e hiporreflexia e discreta resposta à dor em membros torácicos(mais evidente no esquerdo).Os pontos usados: ID3,B62,R3/B60,BP6/VB39,B17, BP10,IG4,IG15 e agulha e moxa em B23,VG4,VG14 e B12 conforme avaliação clínica.Fitoterapia chinesa: Du Huo Ji Shen Tang, Guei Fu Di Huang Wan, Angélica sinensis,Bu Yang Huan Wu Tang, Gui Pi Tang. Na $1^{2}$ semana, animal conseguiu se locomover, com claudicação discreta do membro torácico esquerdo, evolução boa a cada sessão.Podemos observar que estas terapias associadas 
podem conseguir bons resultados em alterações locomotoras, dependendo do grau de lesão nervosa. Quando não há possibilidade de cirurgias e casos refratários a tratamentos médicos conservadores, a acupuntura e fitoterapia chinesa podem ser colocados ao proprietário como opção terapêutica.

\section{6 - Síndrome úveo-dermatológica do Akita com comprometimento neurológico. Relato de 4 casos}

Morales, A.'

\section{1- Clínica Oftalmopet, Valinhos-SP}

Descrevem-se a seguir 4 casos de síndrome úveo-dermatológica com comprometimento neurológico em cães da raça Akita atendidos em clínica particular entre os anos de $2000 \mathrm{e}$ 2002. O relato reveste-se de importância devido à quase inexistência de relatos de acometimento neurológico nesta sindrome. Alguns autores chegam mesmo a questionar sua ocorrência no cão. A sindrome é uma doença auto-imune cujas células-alvo são os melanócitos, resultando em uveítes anteriores, posteriores e panuveítes, dermatopatias com poliose e vitiligo, alem de possivel acometimento de junções muco-cutâneas, semelhantemente à Síndrome de Vogt-Koyanagi-Harada dos humanos. Nestes, porém, os sinais neurológicos são relativamente comuns devido à afecção das meninges. No cão, principalmente Akita $\mathrm{e}$ outras raças a doença é vista com relativa freqüência em serviços de oftalmologia, porém os relatos de sinais neurológicos são muito raros. Caso $n^{\circ} 1$ : fêmea branca de 1 ano e 2 meses de idade, atendida inicialmente com quadro de panuveíte grave e lesões ulceradas em plano nasal. Após corticoterapia local e sistêmica recuperou a visão, porém evoluiu rapidamente para catarata secundária bilateral. Promoveu-se, então, atrofia iatrogênica bilateral para permitir suspensão da corticoterapia. Decorridos 3 meses sem medicação a mesma apresentou inclinação da cabeça e deambulação em círculos com severa desorientação. A sintomatologia cedeu com prednisona oral $(1 \mathrm{mg} / \mathrm{kg}$ ), com doses decrescentes até $0,5 \mathrm{mg} / \mathrm{kg}$ semanal. Caso $\mathrm{n}^{\circ}$ 2: macho branco de 4 anos e meio de idade, atendido inicialmente com panuveíte severa e descolamento parcial de retina. Após três semanas de terapia houve total recuperação. Manteve-se bem com dose de prednisona $0,8 \mathrm{mg} / \mathrm{Kg}$ SID por 1 ano e em seguida a mesma dose EDA por 6 meses, após o que manifestou piora da uveíte, com perda visual progressiva por seqüelas da uveíte e catarata secundária. Procedeu-se à atrofia iatrogênica com suspensão da medicação sistêmica. Após 4 meses, o mesmo apresentou um episódio convulsivo, além de inclinação da cabeça e deambulação em círculos. $O$ exame de líquor demonstrou aumento de globulinas. Tratado novamente com prednisona $(0,5 \mathrm{mg} / \mathrm{kg}$ SID) o quadro neurológico foi controlado. Mantém-se atualmente bem com deflazacort ( $0,5 \mathrm{mg} /$ $\mathrm{kg} \mathrm{EDA}$ ). Caso $\mathrm{n}^{\circ} 3$ : macho tigrado de 3 anos de idade, atendido com uveite severa bilateral, vitiligo de mucosa oral e inclinação da cabeça. Após 14 dias houve melhora considerável, sem inclinação da cabeça e com perda de acuidade visual em olho direito por seqüela de corioretinite. Após 9 meses bem, com prednisona na dose de $0,7 \mathrm{mg} / \mathrm{kg} \mathrm{SID}$, apresentou glaucoma direito, refratário à medicação. Iniciou-se medicação preventiva para glaucoma no olho esquerdo (maleato de timolol 0,5\% SID), porém decorridos 2 meses houve grave crise de glaucoma com evolução desfavorável para cegueira mesmo tendo-se controlado a PIO. $\mathrm{O}$ proprietário ainda não se resolveu pela atrofia, está fazendo redução da dose de prednisona e ainda não houve recidiva da inclinação da cabeça. Caso $n^{\circ} 4$ : fêmea branca de 3 anos de idade. Foi atendida com uveite severa e catarata matura bilateral, sem prognóstico de visão. Apresentava inclinação da cabeça, deambulação em círculos e nistagmo horizontal. Após 3 semanas de corticoterapia apresentou melhora da dor ocular com sinais de progressão para phitisis bulbi, melhora do humor, sem nistagmo e melhora da inclinação da cabeça. A dose da medicação foi diminuida gradualmente até $0,4 \mathrm{mg} / \mathrm{kg}$ SID, com a qual se mantém atualmente, sem qualquer sinal neurológico. Houve atrofia ocular espontânea, o que permite tentar nova diminuição da dose da prednisona. 